\title{
Heterotopiczna koegzystencja żywych i umarłych we współczesnej prozie irańskiej
}

\author{
Heterotopic Coexistence of the Living and the Dead in Contemporary Iranian Fiction
}

\begin{abstract}
The paper addresses the issue of the traces of traditional cultural patterns of coexistence of the living and the dead in Iranian fiction by analyzing the structure of the heterotopies in two novels by female writers, namely Tuba and the Meaning of Night (Tuba va ma'nā-ye šab) by Šahrnuš Pārsipur and Gypsy by the Fire (Kouli-ye kenār-e ātašs) by Moniru Ravānipur. It also acknowledges the literary potential of spatial representation and metaphors in women's identity discourse and the reframing of traumatizing experiences, as well as other problems of society in transition between the traditional social structure and modern individualism.
\end{abstract}

Keywords: Iranian fiction, heterotopy, Šahrnuš Pārsipur, Moniru Ravānipur, women's literature

\begin{abstract}
Abstrakt: Artykuł podejmuje kwestię śladów tradycyjnych wzorców kulturowych współistnienia żywych i umarłych we współczesnej prozie irańskiej. Analizując struktury heterotopii w dwóch powieściach napisanych przez kobiety, tj. Tubā va ma'nā-ye šab (Tuba i znaczenie nocy) autorstwa Šahrnuš Pārsipur i Kouli-ye kenār-e ātaš (Cyganka przy ogniu) pióra Moniru Ravānipur, wykazano wagę literackiego potencjału reprezentacji przestrzeni oraz metafor $\mathrm{w}$ tożsamościowym dyskursie kobiet i przepracowywaniu traumatycznych doświadczeń oraz innych problemów społeczeństwa w okresie przejścia od tradycyjnej struktury do nowoczesnego indywidualizmu.
\end{abstract}

Słowa kluczowe: proza irańska, heterotopia, Šahrnuš Pārsipur, Moniru Ravānipur, literatura kobiet

$$
* * *
$$

Relacja jednostki do tradycji i wspólnoty należy do ulubionych tematów irańskiej literatury współczesnej. Podejmując go, prozaicy często sięgają do przestrzennego potencjału świata przedstawionego. Jednym z zabiegów temu służących jest tworzenie heterotopii, w ramach których żywi koegzystują z umarłymi tak, jakby 
jedni i drudzy współtworzyli jeden świat, a zmarli, zmieniwszy formę istnienia, nie tracili dawnego statusu ontologicznego. W tym artykule przedstawimy to zjawisko na szerszym tle kulturowym, a następnie, analizując dwa szczególnie wyraziste przykłady, poszukamy odpowiedzi na pytanie, na czym polega ich literacki potencjał. Należy dodać, że jest to część szerszego projektu badawczego dotyczącego miejsca i przestrzeni w literaturze irańskiej, tematu tyleż istotnego, co dotąd poważnie zaniedbanego.

Wykorzystana tu definicja heterotopii opiera się na koncepcji Michela Foucaulta ${ }^{1}$. Najogólniej można powiedzieć, że heterotopia jest przestrzenią wyjętą spod władzy codzienności, podporządkowaną własnym prawom, czasem skrzyżowaniem różnych porządków. Pojęcie jest zatem na tyle pojemne, by pomieścić zarówno tradycyjne ,heterotopie kryzysu” (np. miejsca sakralne czy miejsca odosobnienia chorych), jak i miejsca przejściowe, nazywane przez Marca Augé'a „nie-miejscami”, np. lotniskowe poczekalnie ${ }^{2}$. Takie zróżnicowanie każe Foucaultowi zachować ostrożność w formułowaniu definicji, ogranicza się zatem do kilku cech charakterystycznych, takich jak obecność heterotopii w każdej kulturze, jej zmienność w czasie w obrębie kultury, łączenie przestrzeni niekompatybilnych, stosunkowo łatwa dostępność, której może jednak towarzyszyć trudność dostania się do centrum, istoty heterotopii. Szczególnie ciekawą cechę heterotopii z perspektywy niniejszego artykułu stanowi jej powiązanie z warstwami czasu (heterochronia). Modelową heterotopią tego rodzaju jest cmentarz. W pewnym sensie w obu przykładach, które tu analizujemy, właśnie z nim mamy do czynienia, przy czym jest to cmentarz, w którego obrębie zmarli koegzystują z żywymi, tworząc heterotopię par excellence - przestrzeń zhumanizowaną, przestrzeń kultury.

$\mathrm{W}$ irańskiej tradycji można wskazać istotne kulturowo miejsca o podobnej specyfice - przestrzenie liminalne wyłączone z działania praw fizyki. Należą do nich znane tradycji epickiej, a poświadczone jeszcze w źródłach przedislamskich, twierdze mitycznej dynastii Keyānidów, obdarzone magicznymi właściwościami, jak zatrzymanie czasu, które wyłącza jedną z twierdz spod władzy śmierci³ mistyczna kraina Hurkalyā, wywodzona przez mistyków z przedislamskiej geografii mitycznej, która zarazem jest częścią tego świata, jak i przestrzenią z niego wydzieloną, nā-koğa-ābād - nie-miejscem - w którym zachodzi mistyczne doświadczenie ${ }^{4}$. Według dziewiętnastowiecznych szejchitów tam właśnie miał przebywać ukryty imam podczas okultacji ${ }^{5}$. Są to zatem miejsca dostępne śmier-

${ }^{1}$ M. Foucault, Inne przestrzenie, thum. A. Rejniak-Majewska, „Teksty Drugie” 2005, 6, s. 117-125.

${ }^{2}$ M. Augé, Nie-miejsca. Wprowadzenie do antropologii hipernowoczesności, tłum. R. Chymkowski, Warszawa 2012.

${ }^{3}$ A. Ferdousi, Šāhnāme, ed. E. Ğāveini, ğ II, Tehrān 1380 (2001), s. 250-253, Denkard [w:] E.W. West, The Sacred Books of the East, Oxford 1897, http://www.avesta.org/denkard/dk9sbe. html (dostęp: 30.04.2021), IX.21, T.D. Anklesaria (ed., transl.), Zand-Akasih. Iranian or Greater Bundahishn, Bombay 1956, http://www.avesta.org/mp/grb.htm (dostęp: 30.04.2021), Ch. XXXII, s. 212, A. Christensen, Les Kayanides, Copenhague 1932, s. 74-75.

${ }^{4}$ H. Corbin, Spiritual Body and Celestial Earth From Mazdean Iran to Shi'ite Iran, transl. N. Pearson, Bollingen Series XCI: 2, Princeton 1977, T. Purnāmdariān, Aql-e sorx. Šarx o ta'vil-e dāstān-hā-ye ramzi-ye Sohravardi, Tehrān 1390 (2011).

${ }^{5}$ H. Corbin, op. cit. 
telnikom, ale zgodnie z definicją Foucaulta takie, do których centrum trudno dotrzeć - wymaga to wtajemniczenia, mistycznego olśnienia albo nadprzyrodzonej pomocy.

Poza przestrzeniami wyłączonymi z kategorii życia i śmierci istnieją też takie, gdzie te kategorie się przenikają, choć wydawałoby się, że idea koegzystencji żywych i umarłych jest odległa od oficjalnych religii. Idee indywidualnej ścieżki eschatologicznej, sądu ostatecznego, raju i piekła wykształcone na gruncie zaratusztrianizmu - głównej przedislamskiej religii Iranu - były tak wyraziste, że zdaniem badaczy miały zasadniczy wpływ na kształtowanie się podobnych pojęć $\mathrm{w}$ wielkich religiach monoteistycznych ${ }^{6}$. Także $\mathrm{w}$ islamie podkreślana jest przepaść między światem żywych i umarłych. Koran porównuje te światy do dwóch mórz - słodkiego i słonego - rozdzielonych nieprzekraczalną mierzeją - barzax (samo słowo jest średnioperskie i oznaczało pierwotnie miejsce przejściowe, czyściec) ${ }^{7}$. W islamie grób stanowi właśnie barzax - portal pomiędzy dwoma światami, który można przekroczyć tylko w jednym kierunku

$\mathrm{W}$ obu religiach ważny jest szybki pochówek według jasno określonych zaleceń. W zaratusztrianizmie przyjmują one szczególnie rozbudowaną formę ze względu na nieczystość zwłok, zagrażającą według wyznawców tej religii nie tylko żywym, ale nawet żywiołom, jak ogień, woda czy ziemia9. Trudno o jaskrawsze rozgraniczenie świata żywych i umarłych, jednak dotyczy ono tylko wymiaru materialnego, bo zarazem zaratusztrianie wierzą, że trzy dni po śmierci dusza zmarłego pozostaje na ziemi w towarzystwie Sraošy, wysłannika najwyższego bóstwa - Ahura Mazdy ${ }^{10}$. Znają także od starożytności ideę preegzystujących dusz ludzkich - fravaši - żyjących nadal po śmierci, by odtąd opiekować się pozostałymi przy życiu bliskimi i potomkami ${ }^{11}$. Fravaši pozostawały w relacjach z rodziną, a raz do roku miały przybywać na ziemię, by wziąć udział w uczcie przygotowanej przez żywych. Dotąd zaratusztrianie zostawiają na grobach bliskich placki i owoce. Podobne zwyczaje znają irańscy muzułmanie, którzy po śmierci krewnego niosą na jego grób słodycze ${ }^{12}$. Te - zdawałoby się - zanikające

${ }^{6}$ S. Shaked, Eschatology in Zoroatrianism and Zoroastrian Influence [w:] A Collection of Articles from the Encyclopaedia Iranica, ed. M. Mozazzami,, Vol. II, New York 2016, s. 1522-1535; A. Hintze, Defeating Death: Eschatology in Zoroastrianism, Judaism and Christianity [w:] Irano-Judaica VII, eds. J. Rubanovich, G. Herman, Jerusalem 2019, s. 23-72.

${ }^{7}$ Koran 55:9-20. Interpretacja za: A. Buturovic, Funerary Culture in Islam [w:] The Routledge Companion to Death and Dying, ed. Ch.M. Moreman, London-New York 2018, s. 74-85. Podobnie wynika z przekładu perskiego: Qorān mağid, tarğome-ye M.M. Fulādvand, Tehrān-Qom 1976 (1997), natomiast w komentarzu do polskiego przekładu dwa odrębne światy to domeny ludzi i dżinów, por. Koran, tłum., kom. J. Bielawski, Warszawa 1986.

${ }^{8}$ Koran 6:36, 23:99-100 oraz A. Buturovic, op. cit., s. 77.

${ }^{9}$ A. Hintze, Zoroastrian Afterlife Beliefs and Funerary Practices [w:] The Routledge Companion op. cit., s. 86-92.

${ }^{10}$ Eadem.

${ }^{11}$ M. Boyce, Fravaši [w:] Enācyclopaedia Iranica, ed. E. Yarshater, Vol. X, Fasc. 2, s. 195-199, https://iranicaonline.org/articles/fravasi- (dostęp: 30.01.2021).

12 M. Katrāii, Az xešt tā xešt, Tehrān 1378 (1999), s. 285; podobnie podaje S. Hedāyat, Farhang-e āmiyāne-ye mardom-e Irān. Neyrangestān, Usāne, tarāne-hā, āsār-e tahqiqi va āsār-e čāp našăde, gerdāvarande Ğ. Hedāyat, Tehrān 1378 (1999). 
zwyczaje odżyły wraz z powstaniem cmentarzy szahidów (męczenników) - żołnierzy poległych w wojnie z Irakiem, których kult wypełnia ideologiczną przestrzeń republiki islamskiej ${ }^{13}$. Ich symboliczna obecność w przestrzeni publicznej, wyrażana we wszechobecnych plakatach, nazwach ulic, patronacie nad szkołami i rozmaitymi instytucjami, a także w nieustannych wspominkach w mediach, zmienia poniekąd kraj w rodzaj przestrzeni heterotopicznej koegzystencji żywych i umarłych. Państwowa ideologia wykorzystuje stare wzorce męczeństwa i ciągłości życia w rodzinie czy wspólnocie, głęboko zakorzenione w irańskiej tradycji. Powołuje się na sztandarowego męczennika szyitów - imama Hoseyna wnuka Mahometa, który zginął ze swoimi zwolennikami w bitwie pod Kerbelą w roku 680, nie poddawszy się mimo przewagi wojsk nieprzyjaciela ${ }^{14}$. Według szyickiej koncepcji zmarły męczeńską śmiercią, w świętej sprawie, idzie prosto do nieba, a jego ciało pachnie niczym kwiaty. Staje się także szczególnego rodzaju patronem swojej społeczności. Republika islamska nadała status męczenników demonstrantom zabitym podczas rewolucji, a następnie żołnierzom poległym w wojnie z Irakiem (1980-1988), przedstawianej jako wojna w obronie wiary, mimo że po drugiej stronie frontu walczyli także muzułmanie. Do dziś państwo szafuje tytułem męczennika, nadając go np. ofiarom katastrof lotniczych ${ }^{15}$, sprawując w ten sposób rząd dusz. Męczenników przedstawia się w poezji propagandowej i ikonografii w postaci kwiatów - w myśl tej idei oni także nie umierają, a złożeni w ziemi stają się zalążkiem nowego życia ${ }^{16}$.

Taka koncepcja to odrodzenie i zwieńczenie przedislamskiego przekonania o esencjonalnej jedności życia w przyrodzie, a w społeczności ludzkiej - w rodzinie. Przekonania zaczerpniętego z kultów odradzającej się na wiosnę przyrody i przeniesionego na świat ludzki przez kult Siyāvuša, który z bóstwa roślinnego przekształcił się w bohatera ludowych pieśni i eposu. Niesprawiedliwie zabity Siyāvuš odradza się w potomku-mścicielu, który dokonawszy zemsty, będzie kontynuował dzieło i przeznaczenie ojca zakłócone przedwczesną śmiercią ${ }^{17}$. W eposie znajdujemy kilku różnych bohaterów o podobnych cechach. Jednym z nich jest Key Xosrou, postać mesjanistyczna, która według legend, podobnie jak ukryty imam szyitów, przechodzi w stan okultacji, by pojawić się ponownie przy końcu czasów. Ta powtarzalność losów, czy wręcz typów bohaterów w kulturze ludowej, prowadzi do ich utożsamienia - wymieszania poszczególnych historii i postaci w jednej opowieści. Tak właśnie dzieje się z Key Xosrouem w podaniach ludowych, który raz nazywany jest własnym imieniem i wyczekiwany przez zaratusztrian z coroczną ucztą na brzegu jeziora, gdzie miał onegdaj wejść w stan okultacji, kiedy indziej jest samym imamem Hoseynem lub jeszcze innym bo-

13 R. Kaur, Sacralising Bodies. On Martyrdom, Government and Accident in Iran, „Journal of the Royal Asiatic Society" 2010, Series 3, 20, 4, s. 441-460.

${ }^{14}$ W języku polskim o koncepcji szahādatu w kulturze irańskiej pisała Sylwia Surdykowska, por. S. Surdykowska, Idea szahadatu w kulturze Iranu, Warszawa 2006.

15 R. Kaur, op. cit., s. 441-460.

16 P. Chelkowski, H. Dabashi, Staging a Revolution: The Art of Persuasion in the Islamic Republic of Iran, New York 1999.

17 A. Krasnowolska, The Heroes of the Iranian Epic Tale, „Folia Orientalia” 1987, 24, s. $288-293$. 
haterem, przez wieki uśpionym w jaskini, do której czasem znajduje drogę jakiś śmiertelnik, by się go poradzić ${ }^{18}$. Ludowe przekazy mówią także o spotykaniu zmarłych we śnie albo pod postacią psa czy innego zwierzęcia. Można się wówczas z nimi komunikować ${ }^{19}$. Niektóre miejsca na ziemi należą do zmarłych i przebywając w nich, można zostać opętanym przez ducha ${ }^{20}$. Miejsca pochówku nie tylko ważnych postaci religijnych, ale też lokalnych sufich Irańczycy otaczają kultem religijnym. Takie sanktuaria (emām-zāde) słyną z cudów, którymi obdarzają pielgrzymów ${ }^{21}$. W praktyce kulturowej zaciera się zatem przepaść między światem żywych i umarłych. Wydaje się, jakby te światy miały szereg punktów stycznych - szczególnych miejsc i czasów, gdzie się spotykają.

Współczesna literatura irańska, choć przejawia wiele cech uniwersalnych, jest głęboko zaangażowana w intertekstualny dialog z własną tradycją, z którą zdaje się negocjować zakres wolności jednostki uwikłanej w kulturę. Wzorcem inspirującym kolejne pokolenia pozostaje twórczość Sādeqa Hedāyata (1903-1951), pisarza o szerokich zainteresowaniach obejmujących klasyczną literaturę, tradycje przedislamskie i folklor. U Hedāyata pojawia się przestrzeń wielowymiarowa, wyraźnie heterochroniczna i relacje przestrzenne oparte na wewnętrznej geografii doświadczenia postaci, nieprzypominające relacji świata fizykalnego. Szczególnie znamienna jest pod tym względem krótka powieść Buf-e kur (Ślepa sowa) z 1937 roku² . Odnajdujemy w niej przestrzeń, w której relacje czasowe są niejasne, a wydarzenia zdają się powtarzać pewien schemat, osobisty, ale zarazem kulturowy; niczym obrazy na drewnianych piórnikach, które maluje główna postać (narrator), a które są tylko kolejnymi odbitkami obrazu ukształtowanego przez tradycję rzemiosła. Granice między życiem a śmiercią zacierają się, miejsca wydają się pojawiać znikąd i znikać niespodzianie, podobnie jak przejścia do nich, np. okno w domu bohatera, przez które widzi mityczną scenę, która ma się urzeczywistnić ponownie w jego życiu, jak działo się to już wielokrotnie w historii. Hedayāta uznać można za prekursora ważnego nurtu w literaturze współczesnego Iranu - realizmu magicznego. W irańskiej wersji ten typ literatury czerpie zarówno z tradycji ludowej, obfitującej w podania o nadprzyrodzonych istotach i duchach, jak i z literatury klasycznej.

Przejawy heterotopii łączących żywych i umarłych odnajdujemy także w innego rodzaju tekstach, można wręcz powiedzieć, że jest ona dla literatury współczesnej charakterystyczna - częstym motywem i sposobem kształtowania narracji staje się wielogłos różnych postaci, odbijający uwikłanie jednostki w złożone relacje ze zbiorowością i tradycją. Temu wielogłosowi towarzyszyć może heterochronia, jak w przypadku strumienia świadomości, którego bodaj

18 F. Gaštāsb, Oruğ-e Key Xosrou dar revāyat-e šafāhi-ye mardom-e Irān, ,Mağalle-ye ensānšenāsi" 2012, 10/17, 1391, s. 114-131.

19 A. Krasnowolska, The Heroes..., op. cit.

20 G. Sā'edi, Ahl-e havā, Tehrān 1345 (1966), s. 97-100.

21 H. Algar, Emamzada. Function and devotional practice [w:] Encyclopaedia Iranica, Vol. VIII, Fasc. 4, s. 395-397, https://iranicaonline.org/articles/emamzada-i (dostęp: 30.04.2021).

22 S. Hedāyat, Buf-e kur, Tehrān 2536 (1977); polski przekład: S. Hedajat, Ślepa sowa, tłum. B. Majewska, „Literatura na Świecie” 1978, 10/90, s. 5-115. 
najwybitniejszym przejawem w irańskiej literaturze jest $\check{S} \bar{a} z d e$ Ehteğăb (Ksią̇e Ehteğāb) - powieść Hušanga Golširiego (1937-2000) z 1968 roku²3. Pokój księcia kadżarskiego, ostatniego przedstawiciela podupadłego rodu, można określić jako przestrzeń heterotopiczną, właśnie dzięki heterochronii przejawiającej się tu przez wymieszanie czasów różnych okresów życia księcia z czasami jego przodków. Książę uwięziony między duchami, zdolny zająć zaledwie skrawek odziedziczonego krzesła, żyje jednocześnie w różnych czasach, bardziej ze zmarłymi niż z żywymi, co ilustruje scena z zegarami, które uruchamia (w istocie uruchomiła wiele lat przed czasem akcji powieści) narzeczona księcia, a każdy z nich wybija własną godzinę. Z podobną sytuacją mamy do czynienia w Samfoni-ye mordegān (Symfonia umartych, 1989) Abbāsa Ma'rufiego (1957-), gdzie zmarli nie tylko są obecni w życiu (i narracji) żywych członków swojej rodziny, ale wręcz jedna ze zmarłych postaci przejmuje kontrolę nad świadomością żywego, staje się niejako jego głosem ${ }^{24}$.

Także mit Siyāvuša, spleciony z mitem imama Hoseyna, pozostaje żywy w literaturze. Doczekał się uwspółcześnionej wersji w pierwszej powieści kobiecej - Suvašun (1969) Simin Dānešvar (1921-2012)25, której bohaterka, mimo angielskiej edukacji, jaką odebrała, i nieznajomości rodzimych tradycji odkrywa przynależność do wspólnoty mitów, urzeczywistniających się ponownie w jej życiu w realiach historycznych Szirazu okresu II wojny światowej ${ }^{26}$.

Koncepcja ciągłości życia szczególnie wyraźnie odbija się właśnie w najnowszej literaturze pisanej przez kobiety. W ich prozie takie heterotopie, w których żywi i zmarli koegzystują, nabywają dodatkowego wymiaru - stanowią rodzaj projekcji wnętrza bohaterek. Właśnie kobiety, jako bezpośrednio uwikłane w tradycję, pozostają ze zmarłymi w szczególnych relacjach. Omówimy tutaj bliżej dwie tego rodzaju heterotopie, z których każda ma inny charakter. Pochodzą one z powieści: Tuba i znaczenie nocy ${ }^{27}$ (Tubā va ma'nā-ye ša ${ }^{28}$ ) Šahrnuš Pārsipur (ur. 1946) i Kouli-ye kenār-e ātaš (Cyganka przy ogniu) Moniru Ravānipur (ur. 1946) ${ }^{29}$. Obie powieści ukazały się w podobnym czasie - między rokiem 1988 a 2001, zostały docenione przez krytykę i czytelników w Iranie, a także doczekały się przekładów na inne języki. Obie należą do nurtu realizmu magicznego. Każda $\mathrm{z}$ nich zabiera głos $\mathrm{w}$ dyskursie tożsamościowym dotyczącym stosunku kobiety jako jednostki do zbiorowości, ważnym dla literatury tego okresu. Łączy je także próba plastycznego przedstawienia heterotopicznej koegzystencji żywych i umarłych, wyróżniająca się na tle współczesnej literatury irańskiej.

Tuba i znaczenie nocy to powieść zarysowująca panoramę przemian $\mathrm{w}$ dwudziestowiecznym Iranie widzianą oczami kobiety, tytułowej Tuby. Jako młoda

${ }^{23}$ H. Golširi, Šāzde Ehteğāa, Tehrān 1347 (1968).

${ }^{24}$ A. Ma'rufi, Samfoni-ye mordegān, Tehrān 1368 (1989).

${ }^{25}$ S. Dānešvar, Suvašun, Tehrān 1348 (1969).

${ }^{26}$ A. Krasnowolska, Mitologia i ideologia we wspótczesnej literaturze perskiej (na przykładzie „Su va šun” Simin Dānešvar) [w:] Problemy teoretyczne zwiąków literatur Orientu i Zachodu, red. T. Cieślikowska, „Zeszyty Naukowe Uniwersytetu Jagiellońskiego” 1992, MXXXVI.

27 S. Pārsipur, Tuba i znaczenie nocy, tłum. A. Krasnowolska, Kraków 2012.

${ }_{28}$ Š. Pārsipur, Tubā va ma'nā-ye šab, Tehrān 1368 (1989).

${ }_{29}$ M. Ravānipur, Kouli-ye kenār-e ätaš, Tehrān 1378 (1999). 
dziewczyna Tubā odebrała niepełną edukację od swojego biegłego w klasycznym wykształceniu ojca. Z czasem strzępy posiadanych informacji, bardziej utrudniających niż ułatwiających rozumienie zmieniającej się jak w kalejdoskopie rzeczywistości kraju przechodzącego rewolucję cywilizacyjną, uzupełnia naukami mistycznymi i rozmaitymi doświadczeniami osobistymi. Tych ostatnich Tubie nie brakuje: jest córką nadwornego adiba, w którego domu, jako jednym z pierwszych w mieście, pojawia się „Anglik”, żoną starego hādżiego, trzymaną w zamknięciu, miłośniczką kaznodziei okresu rewolucji konstytucyjnej, żoną kadżarskiego księcia - bon vivanta, uczennicą mistrza sufickiego, powiernicą tajemniczych, archetypicznych postaci, surową matką i babką oraz strażniczką ogniska domowego, by wreszcie dostąpić iluminacji i odnaleźć się w roli archetypicznej kobiety-matki, Ewy - antytezy Lilith. Perypetie Tuby, która - wyposażona $\mathrm{w}$ nieprzystający do potrzeb arsenał środków intelektualnych - mierzy się z wyzwaniami świata, którego doświadcza, ale nie umie pojąć i opisać, przedstawione zostały w poetyce realizmu magicznego, co pozwoliło opowieści nabrać wielowymiarowości, a także wyrazić pełne sprzeczności doświadczenie bohaterki. Pojawiają się w tym świecie postaci takie jak książę Gil i jego żona Leylā, snujący wspomnienia z odległych okresów historycznych, aż po początki świata, jak i postaci młode, tragicznie zmarłe, których życiorysy zostały przerwane w pół, jakby za wcześnie, by życie się wyczerpało. Tubā ma szczególną zdolność komunikowania się z nimi. Mianowicie chłopiec, którego Tubā nie zdążyła w porę uratować w czasie wielkiego głodu, otwiera jej oczy na związek suszy i głodu z jej bezpłodnym małżeństwem i daje siłę, by je zakończyć, a młoda dziewczyna - ofiara zabójstwa honorowego, zakopana na podwórku, wiąże Tubę na lata z domem, którego musi pilnować, by zabezpieczyć szczątki podopiecznej. Obecność dziewczyny czyni dom Tuby, wcześniej pełen zwykłej, codziennej krzątaniny, heterotopią, swoistym sanktuarium, w którym doszło do przemiany ladacznicy w świętą patronkę ${ }^{30}$.

Żywa dziewczyna z nieślubnym dzieckiem w brzuchu jest odrażająca i nieczysta. Ta sama dziewczyna, tak uśmiercona może zostać zaliczona w poczet świętych ${ }^{31}$.

Yek doxtar-e zende ke bače-ye harāmi dar šekam-aš dāšte bāšad nefrat-angiz o nağes ast. Hamān doxtar agar intour košte šode bāšad ğozv-e ma'sumin tabaqe-bandi mišavad ${ }^{32}$.

Tubā nazywa ją wprost męczennicą (̌̌ahid) ${ }^{33}$. Dzięki szczególnej nici porozumienia z patronką Tubā może i doznała rozwoju duchowego, ale odsunęła się od żywych, nawet od własnych dzieci. Podwórko z drzewkiem granatu, pod którym pochowano Setāre, jest zatem formą foucaultowskiego heterotopicznego cmentarza - pozornie powszechnie dostępnego, bo położonego w samym sercu domu w rzeczywistości odkrywającego się dla nielicznych. Poza Tubą tylko Leylā, żona księcia Gila, tajemnicza odwieczna femme fatale ${ }^{34}$, wyczuwa obecność Setāre.

\footnotetext{
30 S. Pārsipur, Tuba i..., op. cit., s. 251.

31 Ibid., s. 198.

32 Eadem, Tubā va..., op. cit., s. 189.

33 Ibid., s. 200.

34 Ibid., s. 206, Leylā to postać zaczerpnięta ze wspomnianej Buf-e kur S. Hedāyata.
} 
W kontekście światów przedstawionych powieści Pārsipur nie dziwi, że kobieca wspólnota jest szczególnie wyczulona na kontakt z umarłymi. Wypływa to z jej bliskości z przyrodą, tak silnej, że w innym dziele pisarki, Kobietach bez mężczyzn (Zanān bedun-e mardān), dochodzi do przemiany postaci w drzewo ${ }^{35}$. Substancjalna jedność życia u Pārsipur wiąże się z doświadczeniem kobiecości.

Przejawem różnic w sposobie percepcji świata między kobietami i mężczyznami jest także stosunek do śmierci, co ilustruje rozmowa Tuby z księciem Gilem. Książę opisuje doświadczenie zabójcy, nawet takiego, który działa zgodnie z przykazami kultury, jako doświadczenie wiecznego przesiąknięcia śmiercią, naznaczenia przeszłością, bo zabójca nosi w sobie zawsze trupa ofiary, a ten żyje w przeszłości. Takie doświadczenie stało się udziałem wuja - zabójcy Setāre.

...Tubo, nigdy nie ożywiaj żadnego trupa, nie żyj z trupem. Powiadam ci, niech żywi rodzą żywych, zgodnie z biegiem czasu. Umarli zawsze żyją w przeszłości. Oni są pięknymi wspomnieniami i tymi wspomnieniami duszą cię, jak Starzec Morski, który ci usiadł na karku i owija nogi wokół szyi ${ }^{36}$.

Ammā Tubā hargez hič ğasad rā zende nakon, bā hič ğasadi zendegi nakon. Az man mišenavi, begozār zendegān bezāyand. Ānān bar hasb-e ruh-e zamān mizāyand. Ğasad ammā hamiše dar gozašte zendegi mikonad. U yād-āvar-e selsele-i az xāterāt-e aziz ast. Bā in xāterāt hamānande davālpā dour-e gardan-at halqe mizanand ${ }^{37}$.

Ale dla Tuby, jako kobiety-matki, to doświadczenie jest odmienne: odkrywa, że nowe życie zawsze zawiera w sobie powtórzenie; aby rodzić, trzeba zaakceptować swoją łączność z przeszłością i światem zmarłych. Nawet taka myśl objawia się Tubie za sprawą sygnału przyrody:

Wraz z wybuchem grzmotu coś błysnęło w umyśle Tuby. To, co skrywała ciemność, nagle stało się jasne. Powiedziała:

- Kiedy rodzisz, pojawia się nowa istota, ale dużą część tej istoty stanowią powtórzenia. $\mathrm{W}$ kręgu tych powtórzeń korzystasz z pomocy umarłych ${ }^{38}$.

Zan nāgahān hamrāh bā ghorreš-e ra'd ğaraqe-i dar zehn-aš tarakid, ān-če dar tāriki bud yekān roušan šod. Goft „vaqti mizāyi hasti nou mišavad, ammā baxš-e qābel-e molāheze-i az in hasti rā tekrār-hā taškil midehand, to dar dāyere-ye in tekrār-hā az mordegān komak migiri ${ }^{39}$.

Dlatego, wbrew radzie księcia, Tubā nie porzuca Setāre, a pozwala jej zagarniać coraz więcej przestrzeni - w martwej Setāre widzi nosicielkę życia. Książę ma jednak rację o tyle, że życie z umarłą oznacza stopniowe uleganie jej porządkowi. Setāre

siedziała tylko pod granatem, a jej niewyobrażalnie wielki brzuch zajmował znaczną cześć podwórza. Tubā starała się nie zawadzić o brzuch i chodząc po podwórku, poruszała się teraz tylko ściśle wyznaczonymi ścieżkami. Część podwórza stała się prywatną przestrzenią

\footnotetext{
${ }^{35}$ S. Pārsipur, Kobiety bez mężczyzn, thum. A. Farhadi, Warszawa 2010.

${ }^{36}$ Eadem., s. 219.

37 Eadem, Tubā va ..., op. cit., s. 209.

${ }^{38}$ Eadem, Tuba i..., op. cit., s. 219.

${ }^{39}$ Eadem, Tubā va ..., op. cit., s. 209.
} 
Setāre ${ }^{40}$ zir-e deraxt-e anār minešast o šekam-e bi-had bozorgaš baxš-e qābel-e molāheze-I az hayāt rā mipušānd. Tubā mikušid hangām-e rāh raftan be šekam-e u bar-xord nakonad ${ }^{41}$.

Wreszcie ta szczególna wspólnota kobiet - żywej i umarłej - przejmuje w posiadanie całą przestrzeń domu - dzieci się wyprowadzają, więź zacieśnia się tak bardzo, że zaczynają z sobą rozmawiać, a Setāre, zdolna przemieszczać się i zaglądać w takie przestrzenie jak brzuchy brzemiennych kobiet, pomaga Tubie przepowiadać przyszłość, czy raczej odczytywać jej znaki w teraźniejszości ${ }^{42}$. Powoli staje się jasne, że martwa dziewczyna nie nosi już w sobie życia, nie przyniesie go dziecko, które ją pomści, zabijając swojego ojca-gwałciciela, być może dlatego, że dawni wrogowie nie żyją, a dziecko nie ma już powodu się rodzić ${ }^{43}$.

Nie pojawi się zatem męski mściciel, może dlatego, że pomszczona ma być matka, nie ojciec. Mit ulega przekształceniu. Setāre po latach wydaje owoc, a właściwie wydaje go drzewo granatu, pod którym została pogrzebana. Owocami tego drzewa Tubā w chwili ostatecznej iluminacji podzieli się z ludźmi. Taki wydaje się sens tej dojrzewającej w grobowej samotności wspólnoty kobiecej, niszczącej przez lata wielu żywych - od wuja-zabójcy poczynając, przez brata Setāre i córkę Tuby. Jeśli spojrzeć na to przez pryzmat irańskiej tradycji, Tubā poprzez koegzystencję z mityczną heterotopią swoistego emām-zāde, jakie tworzy w jej domu obecność zwłok Setāre, przekracza granice indywidualnej egzystencji, doświadczając włączenia w życie zbiorowości, w kulturę par excellence, z której przeżywania na poziomie intelektualnym jest wyłączona.

O ile Tubā dojrzewa, podróżując w czasie w zamkniętej przestrzeni - rzadko nawet opuszczając dom - bohaterka Moniru Ravānipur, Āyene, odbywa podróż w ścisłym tego słowa znaczeniu: wygnana przez plemię, podąża za ledwie znanym ukochanym do Teheranu, po drodze doznając zauroczenia wieloma miejscami o magnetycznym oddziaływaniu na ludzi ${ }^{44}$. Wśród nich szczególnie jedno zostało opisane szeroko jako osobliwa heterotopia. Jest to cmentarz, na który Āyene trafia przez nowo poznanych przyjaciół, podobnie jak ona sama jednostki wykluczone z lokalnych wspólnot, na ogół pohańbione, którym udało się umknąć przed zabójstwem honorowym. Błąkają się po obcym mieście jak żebracy. W poszukiwaniu bezpiecznego miejsca schronienia trafiają na stary, zapomniany przez ludzi cmentarz, który wykorzystują bez skrępowania szczególnym charakterem tego miejsca jako swoją kryjówkę, jak przystało na heterotopię, nadając mu nowe funkcje i znaczenia. Wydają się jedynymi panami przestrzeni:

Stary cmentarz, którego zmarli byli już tak nieżywi, że nikt do nich nie zachodził, doświadczał ruchliwych piątków. Kobiety, posprzątawszy swoje groby, prały zużyte ubrania w wodzie z pobliskiej studni, a koło południa rozkładały garnki. Czasem zamiast kamieni do budowy paleniska służyły im kości głowy czy ręki, kości, które niegdyś należały

40 Eadem, Tuba i..., op. cit., s. 228.

${ }^{41}$ Eadem, Tubā va..., op. cit., s. 217.

42 Ibid., s. 252-253.

43 Ibid., s. 251.

${ }^{44}$ K. Rakowiecka-Asgari, Different Interpretations of the Semantics of Space in "The Gypsy by the Fire” ("Kouli-ye kenar-e atash”) by Moniru Ravānipur, ,Studia Litteraria Universitatis Iagellonicae Cracoviensis" 2016, 11, s. 33-40. 
do jakiegoś ciała, czaszki, po których tłukły się myśli, czy to z przekory, czy zadumy nad życiem i światem.

Qabrestān-e qadimi ke mordegān-aš ānqadr morde budand ke digar kasi be sorāgh-e ānhā nemiāmad jom'e-hā-ye por ğanb-o-ğuši dāšt. Zanān-i ke qabr-hā-ye xod rā jāru mikardand, lebās-hā-ye kohne va nax-namā rā bā āb-e čāhi ke dar hamān nazdiki bud mišostand va nazdik-e zohr dighā-ye xod rā bār migozāštand, gāhi be ğā-ye sang az ostāxān-e sari, dasti oğāgh-hā-ye seguš misāxtand, ostāxan-hā-i ke ruzegār-i taxt-e band-e tani bud, ğomğomeha-i, ke andiše-i dar ān be lağăăğ yā az sar-e šuridegi bā zendegi va zamāne dar āvixte bud ${ }^{45}$.

Mogłoby się wydawać, że obejmują tym samym w posiadanie ziemię niczyją. Okazuje się ona jednak należeć do zmarłych, którzy nie dzielą się nią bezinteresownie. Narzucają żywym swoje prawa, zawłaszczają ich do tego stopnia, że W nocy przychodzą się parzyć ( świecie musi do kogoś należeć - jeśli kocha ją żywy, jej serce jest niebieskie i zmarły nie odważy się do niej zbliżyć. Jeśli jednak żywi jej nie chcą, jedynym oparciem stają się martwi, jej serce czernieje i trup bierze w posiadanie jej ciało. „Zmarli znają ludzkie serca"47.

Cmentarz łączy dwa koegzystujące światy - świat żywych wprowadza do niego swój ruch, harmider, żądzę krwi i mord, jedzenie i ogień. Włada nim niepodzielnie w ciągu dnia, ale gdy zapada zmierzch, poddaje się władzy trupów. Jeśli przyjrzeć się temu bliżej, granice przestają być jasne. Sam cmentarz jest żywym organizmem, który karmi się ludźmi. Nawet w sensie dosłownym - odzyskuje żywotność po pogrzebie zabitego w bójce człowieka ${ }^{48}$. Czas zresztą, zgodnie z obserwacją Foucaulta, występuje w tej heterotopii w postaci przeplatających się warstw, heterochronii. W Cygance... dodatkowym jej ogniskiem są historie bohaterów, to snute w postaci opowieści, to przybierające postać groźnych upiorów.

Jeśli przyjrzeć się bliżej, widać, że żebracy nie bez powodu trafiają do krainy zmarłych. Po prostu odnajdują się w niej w mieście, jak wśród swoich. To grupa wyrzutków wygnanych z lokalnych wspólnot, bez możliwości powrotu. Świat, do którego przywykli, rządził się prawami tradycji - prawami zmarłych (qānuni ke morde-hā sāxte budand $)^{49}$. Właśnie z powodu tych praw, których żywi nie potrafili zmienić (jak ojciec głównej bohaterki, któremu wygnanie zhańbionej związkiem z obcym mężczyzną córki z plemienia złamało serce), zostali skazani na banicję albo z trudem uszli z życiem przed zwyczajową karą. Ale zarazem prawa zmarłych są jedynymi, do których ci ludzie nawykli, i pod rządami mieszkańców cmentarza czują się bezpiecznie - oto znowu odnaleźli swoje miejsce w hierarchii.

Cmentarna heterotopia jest więc także alegorycznym krajobrazem kultury w stanie rozpadu. Koegzystencja żywych ze zmarłymi przebiega płynnie, ponie-

\footnotetext{
${ }^{45}$ M. Ravānipur, Kouli..., op. cit., s. 95. Wszystkie przekłady fragmentów tej powieści są autorskie.

${ }^{46}$ Ibid., s. 90.

47 Ibid., s. 92.

${ }^{48}$ Ibid., s. 99.

49 Ibid., s. 141.
} 
waż ulegając prawom zmarłych, żywi nie są już do końca żywymi. Niektórzy, jak tytułowa Cyganka, próbują wrócić do życia, z goryczą konstatując:

Nikt nie może równać się ze zmarłymi. Oni żyją w człowieku tak, że on sam nie zdaje sobie z tego sprawy. Są wszędzie, w cygańskim taborze, w osiadłej wspólnocie. Wiesz, człowiek żyje dzięki obyczajom, a wszystkie obyczaje należą do ludzi dawno zmarłych.

Hič-kas harif-e morde-hā nist, ānhā tu-ye ādam touri zendegi mikonand ke xod-e ādam nemifahmad. Morde-hā hame-ğā hastand, tu-ye qāfele, tu-ye ghabile-ye sāken. Midāni ke ādami be rasm o rosumaš zende ast. Hame-ye rasm o rosum māl-e kasāni-st ke ruzegāri zende bude-and ${ }^{50}$.

Heterotopia cmentarza jest heterotopią wnętrza człowieka uwikłanego w tradycję i zarazem heterotopią społeczeństwa, które próbuje indywidualizacji. Od możliwości zapanowania nad nieładem zależy powodzenie jednego i drugiego. Z tej perspektywy Cyganka, nabierając świadomości, spogląda na problemy społeczne. Odrzucając komunistyczną obietnicę sprawiedliwości społecznej, twierdzi, że to nie bieda jest prawdziwym nieszczęściem ludzi:

Chciałam powiedzieć, że jeśli oni [komuniści - przyp. KR-A] zdołają poradzić sobie z martwymi i zmusić ich do pozostania w grobach i pozostawienia innych w spokoju, to dobrze. W przeciwnym razie, na co się zdadzą ich działania?

Mixāstam beguyam ke agar ānhā betavānand be hesāb-e morde-hā beresand va vādār-e-šān konand ke dar qabr-e xod-e-šān bemānand va kāri bekār-e kasi nadāšte bāšand xub ast. Vagar-na, in kār-hā be če dard mixorand? ?1 $^{51}$

Przez heterotopiczną projekcję bohaterka kobieca zdobywa narzędzie ukazujące strukturę jej doświadczenia, którego, jako analfabetka, nie potrafi należycie opisać słowami. Z poziomu intelektualnego refleksja zostaje przesunięta na obraz doświadczenia i przeżycia, w którym, jak w heterotopii, mieszczą się porządki wzajemnie niekompatybilne. Przedstawienie heterotopiczne przybiera tu formę współczesnego mitu i jak mit łączy przeżycie indywidualne z doświadczeniem zbiorowym.

W powieści Tuba i znaczenie nocy koegzystencja światów żywych i umarłych przebiega inaczej, ale także tutaj umożliwia zrozumienie doświadczenia, dla którego opisu bohaterce brak aparatu intelektualnego. Wobec tej niemocy Tubā uczy się pojmować świat intuicyjnie i na konkretnych przykładach, tworząc osobiste mistyczno-mitologiczne obrazy. W duszy bohaterki koegzystują prosta kobieta i mistyczka, co w żaden sposób nie daje się pogodzić w sferze intelektualnej; dowody tego Tubā daje na każdym kroku, wykazując się skrajną nieumiejętnością abstrakcyjnego myślenia. Jedynie w wymiarze heterotopicznym Tubā ogarnia świat i znajduje uzasadnienie dla swojego istnienia - staje się strażnikiem tajemnicy. Nawykła do takich doświadczeń Tubā zaczyna z czasem żyć bardziej w świecie wewnętrznym, bardziej ze zmarłymi niż z żywymi. Setāre żywi się jej życiem, ale zarazem to dzięki niej Tubā doznaje głębokiej wewnętrznej przemiany i, gdy wreszcie nadchodzi czas, dzieli się z innymi owocami drzewa, pod

\footnotetext{
50 Ibid.

51 Ibid.
} 
którym spoczęła Setāre - granatami - w tradycji irańskiej symbolizującymi nie śmierć, a życie i płodność. Jeśli w Cygance przy ogniu świat zmarłych pochłaniał świat żywych, w Tubie... wymaga on od żywych ofiar, ale w ostatecznym rozrachunku rozwija i wzbogaca ich świat.

Co ciekawe, także w Cygance... ostateczne zakorzenienie bohaterek w mieście nie obyło się bez pośrednictwa zmarłych. Wynosząc z opuszczonych podczas rewolucji domów ubrania, zaczęły się w nie przebierać, a z czasem nadawać sobie imiona zmarłych Ormianek, do których ubrania należały ${ }^{52}$. Wyładniały od tego i dostały „nową skórę", ale to przecież nie była ich własna skóra - zajęły miejsce zmarłych, którzy rzeczywiście odeszli, inaczej, niż to miało miejsce na cmentarzu. Trudno, notabene, o lepszą parabolę społecznego wymiaru rewolucji, nie tylko irańskiej.

Zarówno w Tubie..., jak i w tym epizodzie Cyganki... życie zdaje się przepływać między bohaterami, wiążąc się bardziej z miejscem czy przedmiotem niż konkretną osobą, w myśl wspomnianej wyżej idei substancjalnej jedności życia we wspólnocie. Granica pomiędzy życiem a śmiercią nie jest jednoznaczna, a płynna. Światy koegzystują ze sobą, a między nimi dochodzi wciąż do wymiany za pośrednictwem ,wspólnych mieszkańców”. Właśnie w człowieku te światy się zbiegają. Jeśli świat zmarłych próbuje zawłaszczać świat żywych, to jest to walka bohatera $\mathrm{z}$ trupem $\mathrm{w}$ sobie, $\mathrm{z}$ własnym bagażem demonów.

Ravānipur, zapytana kiedyś o wpływy południowoamerykańskiego realizmu magicznego na swoją twórczość, odpowiedziała, że we własnym poczuciu jest raczej pod przemożnym wpływem irańskiego eposu ${ }^{53}$. Jej historie wywodzą się ze starannie studiowanych lokalnych bajek i legend - poświęca bardzo wiele czasu gromadzeniu materiału ${ }^{54}$. Z tych inspiracji rodzi się szczególna poetyka i obrazowanie jej tekstów. Tym bardziej ciekawe jest, że wydźwięk tych opowieści jest tak różny. Bajki z okolic, z których pochodzi bohaterka jej powieści, odzwierciedlają świat patriarchatu - kobiety rzadko mają w nich do odegrania oryginalną rolę, na ogół definiowane są przez swoje role społeczne ${ }^{55}$. Inaczej u Ravānipur: folklorystyczne rekwizytorium służy jej do wszczęcia dyskusji z tradycją. Kobiety, główne bohaterki jej tekstów, są postaciami aktywnymi. W swojej podróży uczą się wymijać przestrzenie kulturowe, które oferują bezpieczeństwo za cenę wolności. Biorąc pod uwagę irańskie uwarunkowania kulturowe, cmentarz jest najistotniejszą z takich przestrzeni, ponieważ to ostoja tradycyjnego porządku społecznego, w którym żywy ma miejsce wyznaczone przez wspólnotę, przez zmarłych. Jednostka definiuje się zatem jako część wspólnoty, realizująca powtarzany przez kolejne pokolenia schemat. Cmentarz Ravānipur daje się też łatwo interpretować jako obraz zdominowanej przez kulturę męczeństwa przestrzeni

52 Ibid., s. 224-225.

53 M. Ravānipur w: Contemporary Iranian Fiction in Translation. A panel discussion with Moniro Ravanipour, Mohamad Ghanoonparvar, Fatemeh Shams, Mahyar Entezari, Kelly Writers House, https://www.youtube.com/watch?v=LoCSUPkWNX0\&t=3896s (dostęp: 30.04.2021).

54 Ibid.

55 E. Friedl, Women in Contemporary Persian Folktales [w:] Women in the Muslim World, eds. L. Beck, N. Keddie, Harvard 2013, s. 629-650. 
publicznej porewolucyjnego Iranu, którą odnajdujemy w innych dziełach pisarki w postaci procesji pogrzebowych, dominujących w mieście tak, jak wspólnota dominuje nad jednostką poświęcającą się dla ogółu ${ }^{56}$.

Pārsipur toczy podobny dyskurs z tradycją, przy czym dla niej punktem wyjścia nie są ludowe podania, a tradycja mistyczna. Tutaj także kobiety przejmują stare repozytorium kulturowe: ofiara zabójstwa honorowego, obmyta ze zmazy własną krwią, tworzy wokół siebie przestrzeń świętą na wzór emām-zāde. Uświęcona przestrzeń okazuje się heterotopiczna także w sensie wielowymiarowości. Dotarcie do centrum, okupione latami mistycznej praktyki, otwiera Tubie drogę do „nie-miejsca”, gdzie jak inni mistycy, doświadcza olśnienia. Tubie udaje się zatem zrealizować w wymiarze wyznaczonym przez kulturę, ale w wymiarze indywidualnym ta realizacja oznacza śmierci i anihilację - dla abstrakcyjnej wspólnoty doświadczenia mistycznego Tubā odrzuca bliskich.

Podsumowując, obie heterotopie wykorzystują elementy tradycji kulturowych, które reorganizują w obraz zmagań jednostki i społeczeństwa w trakcie przemian, rozdarcia między duchami przeszłości, prawami wspólnoty a rozwojem indywidualnym. Heterotopia jest rodzajem czyśćca, który dzięki projekcji wewnętrznych napięć w przestrzeń wspólną pozwala doświadczyć katharsis, uwalniając od groźby choroby psychicznej dzięki przepracowaniu traumatycznego doświadczenia. Zarazem takie obrazowe przedstawienie wewnętrznych problemów postaci pozwala zobaczyć je jako element szerszego, historycznego i społecznego, procesu przemian tożsamościowych. Co więcej, wprowadza do społecznej narracji doświadczenie przemilczane - użycza głosu prostym, niepiśmiennym kobietom. Dosłownie stwarza przestrzeń oddającą wielowymiarowość wewnętrznego doświadczenia bohaterek w perskiej literaturze, ukazywanych tradycyjnie jedynie przez pryzmat atrybutów zewnętrznych - urody czy miejsca w strukturze społecznej, tj. roli matki, kochanki czy kobiety upadłej. A przecież właśnie te atrybuty zostają tu wykorzystane, z tą różnicą, że nabierają dynamizmu.

Jak to ujął Brian McHale, wykorzystanie w literaturze takich środków jak heterotopie umożliwia oddanie „ontologicznego obrazu kultury"57, w przypadku irańskim w jej momencie przejściowym, kiedy stare jest zbyt zmieszane z nowym, by można je było dyskutować w wyabstrahowaniu jako konstrukty ściśle intelektualne. Heterotopia działa zatem jak mit - pozwala dyskursyfikować więzy kulturowe. Realizuje się jako rekonfiguracja mitów starych, jak idea substancjalnej łączności żywych i umarłych członków wspólnoty.

${ }^{56}$ M. Ravānipur, Del-e fulād, Tehrān 1379 (2000).

57 B. McHale, Powieść postmodernistyczna, tłum. M. Płaza, Kraków 2012, s. 78. 


\section{Bibliografia (References)}

Algar H., Emamzada. Function and devotional practice [w:] Encyclopaedia Iranica, Vol. VIII, Fasc. 4, s. 395-397, https://iranicaonline.org/articles/emamzada-i (dostęp: 30.04 .2021$)$.

Augé M., Nie-miejsca. Wprowadzenie do antropologii hipernowoczesności, tłum. R. Chymkowski, Warszawa 2012.

Boyce M., Fravaši [w:] Encyclopaedia Iranica, ed. E. Yarshater, Vol. X, Fasc. 2, s. 195-199, https://iranicaonline.org/articles/fravasi- (dostęp: 30.01.2021).

Buturovic A., Funerary Culture in Islam [w:] The Routledge Companion to Death and Dying, ed. Ch.M. Moreman, London-New York 2018, s. 74-85.

Chelkowski P., Dabashi H., Staging a Revolution: The Art of Persuasion in the Islamic Republic of Iran, New York 1999.

Christensen A., Les Kayanides, Copenhague 1932.

Corbin H., Spiritual Body and Celestial Earth From Mazdean Iran to Shi'ite Iran, transl. N. Pearson, Bollingen Series XCI: 2, Princeton 1977.

Dānešvar S., Suvašun, Tehrān 1348 (1969).

Denkard [w:] E.W. West, The Sacred Books of the East, Oxford 1897, http://www. avesta.org/denkard/dk9sbe.html (dostęp: 30.04.2021).

Ferdousi A., Šāhnāme, ed. E. Ğāveini, ğ II, Tehrān 1380 (2001).

Foucault M., Inne przestrzenie, tłum. A. Rejniak-Majewska, „Teksty Drugie” 2005, 6, s. 117-125.

Friedl E., Women in Contemporary Persian Folktales [w:] Women in the Muslim World, eds. L. Beck, N. Keddie, Harvard 2013, s. 629-650.

Gaštāsb F., Oruğ-e Key Xosrou dar revāyat-e šafāhi-ye mardom-e Irān, „Mağalle-ye ensān-šenāsi” 2012, 10/17, 1391, s. 114-131.

Golširi H., Šāzde Ehteğāb, Tehrān 1347 (1968).

Gruber C., The Martyrs' Museum in Tehran: Visualizing Memory in Post-Revolutionary Iran, "Visual Anthropology" 2012, 25, s. 68-97.

Hedajat S., Ślepa sowa, tłum. B. Majewska, „Literatura na Świecie” 1978, 10/90, s. 5-115.

Hedāyat S., Buf-e kur, čāp-e ğadid, Tehrān 2536 (1977).

Hedāyat S., Farhang-e āmiyāne-ye mardom-e Irān. Neyrangestān, Usāne, tarānehāa āsār-e tahqiqi va āsār-e čāp našāde, gerdāvarande Ğ. Hedāyat, Tehrān 1378 (1999).

Hintze A., Defeating Death: Eschatology in Zoroastrianism, Judaism and Christianity [w:] Irano-Judaica VII, eds. J. Rubanovich, G. Herman, Jerusalem 2019, s. $23-72$.

Hintze A., Zoroastrian Afterlife Beliefs and Funerary Practices [w:] The Routledge Companion to Death and Dying, ed. Ch.M. Moreman, London-New York 2018, s. 86-92.

Katrāii M., Az xešt tā xešt, Našr-e Sāles, Tehrān 1378 (1999).

Kaur R., Sacralising Bodies. On Martyrdom, Government and Accident in Iran, ,Journal of the Royal Asiatic Society" 2010, Series 3, 20, 4, s. 441-460.

Koran, thum i kom. J. Bielawski, Warszawa 1986.

Krasnowolska A., Mitologia i ideologia we współczesnej literaturze perskiej (na przykładzie „Su va šun” Siminin Dānešvar) [w:] Problemy teoretyczne związków lite- 
ratur Orientu i Zachodu, red. T. Cieślikowska, „Zeszyty Naukowe Uniwersytetu Jagiellońskiego" 1992, MXXXVI.

Krasnowolska A., The Heroes of the Iranian Epic Tale, „Folia Orientalia” 1987, 241987, s. 288-293.

Ma'rufi A., Samfoni-ye mordegān, Tehrān 1368 (1989).

McHale B., Powieść postmodernistyczna, tłum. M. Płaza, Kraków 2012.

Milāni F., Words Not Swords: Iranian Women Writers and the Freedom of Movement, Syracuse-New York 2011.

Pārsipur S., Kobiety bez mężczyzn, tłum. A. Farhadi, Warszawa 2010.

Pārsipur S., Tuba i znaczenie nocy, tłum. A. Krasnowolska, Kraków 2012.

Pārsipur Š., Tubā va ma 'nā-ye šab, Tehrān 1368 (1989).

Purnāmdariān T., Aql-e sorx. Šarx o ta'vil-e dāstān-hā-ye ramzi-ye Sohravardi, Tehrān 1390 (2011).

Qor'ān mağid, tarğome-ye M.M. Fulādvand, Tehrān-Qom 1376 (1997).

Rakowiecka-Asgari K., Different Interpretations of the Semantics of Space in "The Gypsy by the Fire” (“Kouli-ye kenar-e atash”) by Moniru Ravānipur, „Studia Litteraria Universitatis Iagellonicae Cracoviensis" 2016, 11, s. 33-40.

Ravānipur M., Del-e fulād, Tehrān 1379 (2000).

Ravānipur M., Kouli-ye kenār-e ātaš, Tehrān 1378 (1999).

Sā’edi G., Ahl-e havā, Tehrān 1345 (1966).

Sadoughianzadeh M., Gender Structure and Spatial Organization: Iranian Traditional Spaces, „SAGE Open” 2013, October-December, s. 1-12, https://journals.sagepub.com/doi/pdf/10.1177/2158244013511258 (dostęp: 30.04.2021).

Shaked S., Eschatology in Zoroatrianism and Zoroastrian Influence [w:] A Collection of Articles from the Encyclopaedia Iranica, ed. M. Mozazzami, Vol. II, New York 2016, s. 1522-1535.

Shams F., Dialogues with the Dead: Necropoetics of Zahra's Paradise, „Iranian Studies" 2020, 53, 5-6, s. 893-909.

Surdykowska S., Idea szahadatu w kulturze Iranu, Warszawa 2006.

Zand-Akasih. Iranian or Greater Bundahishn, ed., transl. T.D. Anklesaria T.D., Bombay 1956, http://www.avesta.org/mp/grb.htm (dostęp: 30.04.2021).

Film

Contemporary Iranian Fiction in Translation. A panel discussion with Moniro Ravanipour, Mohamad Ghanoonparvar, Fatemeh Shams, Mahyar Entezari, Kelly Writers House, https:/www.youtube.com/watch?v=LoCSUPkWNX0\&t=3896s (dostęp: 30.04.2021). 